\title{
PENAHAPAN PLOT DALAM KARYA FIKSI
}

\author{
Mustika Ratu M. \\ Fakultas Sastra, Universitas Muslim Indonesia \\ Jalan Urip Sumoharjo KM 5, Makassar \\ mratu907@gmail.com
}

\begin{abstract}
Abstrak: Penahapan plot bertujuan untuk mengetahui tentang pemahaman tahap plot awal, tengah, akhir. Dunia mengenai telaah prosa sebagai salah satu genre sastra, di samping genre-genre sastra lainnya. Ia dapat mencakup berbagai karya tulis dalam bentuk prosa bukan dalam bentuk puisi atau drama. Prosa dalam pengertian kesastraan disebut fiksi, teks naratif atau wacana naratif. Penahapan plot merupakan unsur pengenalan tokoh-tokoh, baik fisik maupun perwatakannya. Kaidah pemplotan masaalah kreativitas,Kebaharuan,dan keaslian dapat juga menyangkut masalah pengembangan plot.Pengarang memiliki kebebasan untuk memilih cara untuk mengembangkan plot, membangun konflik, menyiasati penyajian peristiwa, dan sebagai sesuai dengan selera estetisnya. Penampilan peristiwa demi peristiwayang hanya mendasari diri dari urutan waktu saja belum merupakan plot, agar menjadi suatu plot maka peristiwa-peristiwa tadi harus diolah dan disiasati secara kreatif. Sehingga hasil pengolahan dan penyiasatan itu sendiri merupakan sesuatu yang indah dan menarik, khususnya dalam kaitannya dengan karya fiksi yang bersangkutan secara keseluruhan. Sifat plot misterius dan intelektual menampilkan kejadiankejadian yang mengandung konflik yang mampu menarik atau bahkan mencekam pembaca.
\end{abstract}

Kata Kunci: penahapan plot, sastra, karya fiksi

\section{PENDAHULUAN}

Awal peistiwa yang ditampilkan dalam sebuah teks fiksi seperti disinggung diatas, Mungkin saja langsung berupa adegan-adegan yang tergolong menegangkan. Pembaca langsung dihadapkan pada peristiwa cerita yang berkadar komplit dan dramatik tinggi, yang barangkali, justru merupakan komplit yang amat menentukan plot cerita fiksi bersangkutan. Padahal, pembaca belum lagi dibawa masuk kedalam suasana cerita, belum lagi tahu awal mula, dan sebabsebab terjadinya komplit. Cerita yang diawali dengan tanpa basa-basi dan langsung masuk ke inti permasalahan, adalah cerita yang menampilkan plot.

Hal demikian dapat terjadi disebabkan oleh urutan waktu penceritaan (jadi secara linear, subjek) sengaja dimanupulasikan dengan urutan peristiwa (logika fafula) yang mungkin dimaksudkan untuk mendapatan bentuk pengucapan baru dan aristik tertentu, suprise, ataupun bentuk suspense dipihak pembaca.

Plot sebuah cerita bagaimana pun tentulah mengandung unsur urutan waktu, baik dimukakan secara eksplisit maupun emplisit. Oleh karena itu, dalam sebuah cerita, sebuah teks naratif, tentulah ada awal kejadian. Kejadian-kejadian berikutnya barangkali adapula akhirnya. Namun plot sebuah cerita fiksi sering tidak menyajikan urutan peristiwa secara kronologis dan runtuk melainkan penyajian yang dimulai dan di akhiri dengan kejadian yang manapun juga tanpa 
ada keharusan untuk memulai dan mengakhiri dengan kejadian awal.

Secara teoretis plot dapat di urutkan atau di kembangkan dalam tahapan-tahapan tentu secara kronologis namun, dalam praktiknya dan langkah “operasional". Yang dilakukan pengarang tidak selamanya tunduk pada teori itu.

\section{PEMBAHASAN}

\section{Tahapan Awal}

Tahapan sebuah cerita biasanya disebut sebagai tahapan perkenalan. Tahapan perkenlan pada umumnya berisi sejumlah informasi penting yang berkaitan dengan berbagai hal yang menunjukkan dan pengenalan latar, seperti nama-nama tempat, suasana alam, waktu kejadiannya (misalnya ada kaitannya dengan waktu sejarah, dan lain-lain pada garis besarnya berupa deskripsi seting).

Fungsi pokok tahapan awal (pembukaan) sebuah cerita adalah untuk memberikan informasi dan penjelasan seperlunya khususnya yang berkaitan dengan peralatan dan penokohan. Dengan pembaca pelukisan latar yang hidup itu, pembaca yang berpengalaman sudah akan dapat "menilai" gaya, kejelian, ketelitian, dan kepekaan pengarang terhadap keadaan latar yang di ikiskan tersebut.

Sepasang burung bangau melayang meniti angin berputar-putar tinggi dilangit tanpa sekali pun mengepak sayap. Mereka mengapung berjam-jam lamanya.

Pada dasarnya setiap adegan cerita membutuhkan pembukaan, baik berada diawal maupun ditengah cerita. Oleh karena itu, deskripsi latar seperti contoh diatas dapat berkali-kali dijumpai dalam sebuah karya (novel). Mungkin pada setiap bab, bahkan mungkin juga disisipkan dibagian tengah bab-bab tertentu.

Tahapan awal berupa pengenalan tokoh akan membawa pembaca untuk segera perkenalan (mengenali) dengan tokoh yang akan dikisahkan. Dengan cara ini kita pembaca segera mengetahui tentang "usia dan siapa dan bagaimana" tokoh-tokoh ini berhubungan dengan jati diri tokoh-tokoh tersebut.

\section{Tahapan Tengah}

Tahapan tengah cerita yang dapat juga disebut sebagai tahapan pertikaian menampilkan pertentangan dan komplit yang sudah mulai ditampilkan pada tahapan sebelumnya, Menjadi semakin meningkat, semakin menegankan. Komplit yang dikisahkan seperti telah dikemukakan diatas, dapat berupa komplit internal, komplit yang terjadi dalam diri seseorang tokoh, komplit eskternal atau pertengtangan yang terjadi antar tokoh cerita, antar tokoh-tokoh protagonis dan tokoh-tokoh dalam kekuatan antagonis, atau keduanya sekaligus.

Bagian tengah cerita merupakan bagian terpanjang dan terpenting dalam sebuah cerita fiksi yang bersangkutan. Pada bagian inilah inti cerita disajikan: tokoh-tokoh memainkan peran, peristiwaperistiwa penting fungsional dikisahan, komplit berkembang semakin meruncing, menegankan dan mencapai klimaks, dan pada umumnya tema pokok, makna pokok cerita diugkapkan. Dan apa tema dan atau makna utama cerita, diperlukan kajian yang jeli dan kritis singkatannya, pada bagian inilah terutama pembaca memperoleh cerita, memperoleh suatu dari kegiatan pembacanya. 


\section{Tahapan Akhir}

Sebuah cerita atau dapat juga disebut tahapan pelarian, menampilkan adegan tertentu sebagai akibat klimas. Jadi, bagian ini misalnya (antara lain), berisi bagaimana kesudahan cerita, atau merayakan padahal bagaimanakah akhir sebuah cerita. Pembaca sebuah karya cerita yang menegakkan, yang tinggi kadarnya, dan bagaimanakah pula akhirnya (pengakhirannya) yang ada dalam hal ini biasanya dikaitan dengan bagaimana "nasib" tokoh-tokoh. Bagaimana bentuk penyelesaian sebuah cerita, dalam banyak hal ditentukan (atau dipengaruhi) oleh hubugan antar tokoh dan komplit termasuk klimaks yang dimuculkan.

Dalam teori klasik yang berasal Aristoteles, penyelesaian cerita dibedakan kedalam dua macam kemungkinan: Kebahagian (Happy End) dan kesedihan (Sad End). Pembedaan itu lebih didasarkan pada kenyataan karya-karya yang telah pada waktu itu, misalnya buku-buku drama tragedi karya Sophocles. Kedua jenis penyelesain tersebut juga banyak dijumpai dalam novel-novel indonesia pada awal pertumbuhannya. Penyelesaian cerita yang dapat dikategorikan sebagai cerita yang berakhir dengan kebahagian misalnya berupa perkawinan dua anak manusia yang saling mencintai seperti pada novel pertemuan jodoh, asmara jaya. Salah pilih, layar terkembang, dan ayatayat cinta.

Pada umunya pembaca diam-diam menuntuk agar cerita diselesaikan. Artinya, para tokoh akan memperoleh "Imbalan" dari perilakunya selama ini. Jika tidak, mereka boleh jadi merasa kecewa atau kurang puas karena harapannya tidak kesampaian. Pembaca menhendaki adanya katarsis dan sekaligus keadilan puitis:Tokoh baik dibahagiakan, sedangkan Tokoh jahat dihukum.

Jika pembaca secara kritis berbagai novel yang ada didalam kesastraan indonesia, dengan mendasarkan pada dua jenis penyelesaian cerita seperti diatas, berangkali kita akan lebih sering merasa kerepotan untuk menentukan apakah sebuah novel berakhir dengan kebahagian atau kesedihan bahkan lebih dari itu, kita pun merasakan kesulitan untuk mengatakan apakah novel itu memang sudah "berakhir" tersebut tentu saja dalam kaitan dengan logika cerita, artinya cerita memang sudah selesai. Cerita sudah habis karena, Misalnya tokoh-tokoh cerita dimatikan seperti pada asap dan sengsara dan Siti Nurbaya.

Namun, Novel-novel seperti belengguh, pada sebuah kapal kemeluk hidup, Burung-burung manyar, Burungburung Rantau, Jantera biang lala, super nofa, bilangan $f u$, dan lain-lain adalah contoh yang (penyelesaiannya). Apakah belengguh berakhir dengan kebahagiaan? Namun, benarkah ceritanya telah berakhir habis tidak ada lagi kelanjutannya. Penyelesaian cerita yang masih "menggantung" masih menimbulkan tanda tanya tidak jarang menimbulkan, bahkan rasa ketidakpuasan pembaca sepenuhnya diselesaikan. Tokoh-tokoh cerita belum (semuanya). Ditentukan "nasib"-nya sesuai dengan perang yang diembangnya. Sebagai contoh untuk kasus kesastraan indonesia adalah yang telah dikemukakan di atas.

Dilihat dari kesempatan pembaca untuk ikut serta "campur tangan" dalam pemikiran penyelesaian cerita itu, Pada penyelasaian tertutup pembaca tidak 
mempunyai kesempatan "ikut" menentukan kemungkinan penyelesaian cerita itu secara lain. Penyelesaian cerita telah ditentukan secara pasti (dan sepihak) oleh si embunya cerita dan pembaca tinggal menerima apa yang ada, mau tidak mau sependapat atau tidak sependapat.

Akhirnya perlu kembali ditegaskan bahkan ketiga tahap plot di atas saling berkaitan untuk membentuk sebuah kepaduan cerita, lepas darimana letak mereka masing-masing pada urutan sintakmatik cerita. Tahap awal cerita membawa kita dari eksposisi dan pengenalan setting ke tanda-tanda munculnya komplit, tahap tengah menyajikan semakin meningkatnya komplit pertautan dan kompletksitas komplit untuk akhirnya sampai ke klimaks yang semuanya itu merupakan inti cerita, dan tahap akhir membawa kita dari klimaks ke penyelesaian.

\section{Tahapan Plot: Rincian Lain}

Selain rincan tahapan plot sebagaimana dikemukakan di atas, ada tahapan lain yang dimaksud adalah yang ditemukan oleh tasrif (dalam emochard summer?) yaitu yang membedaan tahapn plot menjadi lima bagian.

Lima tahapan itu adalah sebagai berikut:

1. Tahapan situation (Tasrif juga memakai istilah dalam Bahasa Inggris): Tahap penyituasian, tahap yang terutama berisi pelukisan dan pengenalan situasi latar dan tokohtokoh cerita. Tahap ini merupakan tahap pembukaan cerita, Pemberian informasi awal, dan lain-lain yang terutama. Fungsi untuk melands tumpai dikisahkan pada tahap berikutnya.
2. Tahap Generating circumstances: Tahap pemunculan komplit, masalah dan peristiwa-peristiwa yang menyulut terjadi komplit mulai dimunculan. Jadi tahapan, ini merupakan tahapan awal munculnya komplit, dan komplit itu sendiri akan berkembang dan atau dikembangkan menjadi komplitkomplit pada tahap berikutnya. Pada tahap pertama dan kedua pada pembagian ini tampaknya berkesesuaian dengan tahap awal pada penahapan seperti yang dikemukakan di atas.

3. Tahap climaks: Tahapan klimaks, komplit atau pertentangan yang terjadi, yang dilakukan atau ditimpahkan kepada para tokoh cerita mencapai. Insentitas puncak. Klimaks sebuah cerita akan dialami oleh tokoh-tokoh utama yang berperan sebagai pelaku dan penderita tejadinya komplit utama.

4. Tahap rising acition: Tahap peningkatan komplit, komplit yang telah dimunculkan pada tahap sebelumnya semakin berkembang dan dikembangkan intensitasnya.

5. Tahap denouement: Tahap penyelesaian, komplit yang mencapai klimaks yang diberi jalan keluar cerita akhir. Tahap ini berkesesuaian dengan tahap akhir di atas.

\section{PENUTUP}

Awal peristiwa yang ditampilkan dalam sebuah teks fiksi seperti disinggung di atas. Mungkin saja langsung berupa adegan-adegan yang tergolong menegangkan. Pembaca langsung dihadapkan pada peristiwa cerita yang berkadar komplit dan dramatik tinggi, yang barangkali, justru merupakan komplit yang amat menentukan plot cerita fiksi 
bersangkutan. Padahal, pembaca belum lagi dibawa masuk ke dalam suasana cerita, belum lagi tahu awal mula, dan sebab-sebab terjadinya komplit. Cerita yang diawali dengan tanpa basa-basi dan langsung masuk ke inti permasalahan, adalah cerita yang menampilkan plot.

Tahapan awal, tahapan sebuah cerita biasanya disebut sebagai tahapan perkenalan. Tahapan tengah, tahapan tengah cerita yang dapat juga disebut sebagai tahapan pertikaian menampilkan pertentangan dan komplit yang sudah mulai ditampilkan pada tahapan sebelumnya, menjadi semakin meningkat, semakin menegankan. Tahapan akhir, sebuah cerita atau dapat juga disebut tahapan pelarian, menampilkan adegan tertentu sebagai akibat klimas.

\section{DAFTAR PUSTAKA}

Mansyur, U. (2018). Kiat dan Teknik Penulisan Skripsi bagi Mahasiswa. INA-Rxiv. https://doi.org/10.31227/osf.io/juds7

Mansyur, U. (2018). Kiat dan Teknik Penulisan Skripsi bagi Mahasiswa. INA-Rxiv. https://doi.org/10.31227/osf.io/juds7

Muliadi. (2017). Buku Ajar Telaah Prosa: Sebuah Terapan. Makassar: De La Macca.

Nurgiyantoro, B. (2015). Teori Pengkajian Fiksi. Yogyakarta: Gadjah Mada University Press.

Sastra33. (2016). Pengkajian, Pendekatan, Garapan, Gaya, dan Teknik Pengkajian Seni Drama, Teater, dan Film. https://sastra33.blogspot.com. 